\title{
Natural and Derivatized Acetogenins Promising for the Control of Spodoptera frugiperda Smith
}

\author{
José Ruiz Hidalgo' , Eduardo Alberto Parellada1, Lilian Di Toto Blessing1 , Alicia Bardón1,2, \\ Keshav Lalit Ameta ${ }^{3}$, Nancy Vera ${ }^{4}$, Adriana Neske ${ }^{1}$
}

${ }^{1}$ UNT-FBQF-Argentina, Institutode Química Orgánica, Tucumán, Argentina

${ }^{2}$ INQUINOA-CONICET, Tucumán, Argentina

${ }^{3}$ Department of Science, Mody University of Science and Technology, FASC, Lakshmangarh, India

${ }^{4}$ UNT-FBQF-Argentina, Instituto de Farmacia, Tucumán, Argentina

Email: klameta77@hotmail.com, aneske@fbqf.unt.edu.ar

How to cite this paper: Ruiz Hidalgo, J., Parellada, E.A., Di Toto Blessing, L., Bardón, A., Ameta, K.L., Vera, N. and Neske, A. (2016) Natural and Derivatized Acetogenins Promising for the Control of Spodoptera frugiperda Smith. Journal of Agricultural Chemistry and Environment, 5, 200-210.

http://dx.doi.org/10.4236/jacen.2016.54021

Received: August 22, 2016

Accepted: October 31, 2016

Published: November 3, 2016

Copyright $\odot 2016$ by authors and Scientific Research Publishing Inc. This work is licensed under the Creative Commons Attribution International License (CC BY 4.0).

http://creativecommons.org/licenses/by/4.0/

\section{(c) (i) Open Access}

\begin{abstract}
Annonaceous acetogenins (ACG), belonging to the family Annonaceae, represent a class of bioactive compounds whose toxic effects have been reported for several species of insects. Given their insecticidal properties, we first carried out the isolation of the ACG from a Brazilian collection of the seeds of Annona squamosa (Annonaceae) and prepared their methoxy methylated (MOM) and acetylated (OAc) derivatives by chemical methods. ACG analogues were semi-synthesized and characterized by spectroscopic techniques $\left({ }^{1} \mathrm{H}\right.$ and $\left.{ }^{13} \mathrm{C}-\mathrm{NMR}\right)$. We isolated ten natural acetogenins: squamocin, molvizarin, motrilin, rolliniastatin-2, almuñequin, cherimolin-1, cherimolin-2, annonacin, squamocin $\mathrm{D}$ and asiminecin. The main objective of this study is to report the antifeedant, toxic and nutritional effects of three of those natural acetogenins and their acetylated and methoxy methylated derivatives on Spodoptera frugiperda Smith (Lepidoptera: Noctuidae). The natural ACGs squamocin and molvizarin killed $100 \%$ of $S$. frugiperda larvae, followed by motrilin (80\%). Acetylated derivatives had less toxic and nutritional effects that led to pupal mortality and adult fatal malformations. The addition of MOM derivatives to the larval diet has not toxic effects on larvae, but significantly reduces growth rate and efficiency in conversion of ingested food into biomass, affecting adult survival.
\end{abstract}

\section{Keywords}

Acetogenin, Annona squamosa, Spodoptera frugiperda, Acetylated Acetogenin, Methoxy Methylated Acetogenin 


\section{Introduction}

Annona squamosa L. (Annonaceae), is a $6-8 \mathrm{~m}$ tall tree distributed in tropical and subtropical regions of America, and the Caribbean (Puerto Rico, Cuba, etc.), and is also common in El Salvador, Colombia, Peru, Venezuela, Brazil and eastern Bolivia, whose edible fruit is currently incorporated to commercial fruit juices.

Characteristic constituents of these plants are the annonaceous acetogenins that possess unique structures [1] and anticancer [2] [3], cytotoxic [4], insecticidal [5] [6], antiparasitic activities and as a highly interesting new generation of antitumor drugs [7] [8] [9] [10] [11]. Furthermore, acetogenin cytotoxicity would be strongly related to the conformation adopted in the membrane [12] [13] [14].

Regarding the insecticidal action of acetogenins, it has been reported that many of these compounds are toxic to Myzus persicae (Homoptera) adults and Leptinotarsa decemlineata (Coleoptera) [15], as well as to nymphs of the German cockroach [2].

Previous results from our laboratory indicated that some acetogenins from $A$. cherimolia and A. montana have larvicidal effects on the Spodoptera frugiperda (Lepidoptera) corn pest [16] [17], nymphal and adult mortality on the Oncopeltus fasciatus (Hemiptera) cotton pest [18], and insecticidal activity against Ceratitis capitata Wiedemann (Diptera) [19].

The aim of this work is the search of the most active structure of ACG with insecticide action on the polyphagous lepidopteran $S$. frugiperda. For this purpose, we first carried out the isolation of adjacent and no-adjacent, bis-THF ACGs with $\mathrm{OH}$ groups flanking the THF: squamocin (1), molvizarin (2), motrilin (3), rolliniastatin-2 (4), almuñequin (5), cherimolin-1 (6), cherimolin-2 (7), annonacin (8), squamocin D (9), asiminecin (10) (Figure 1) from Annona squamosa. Then, their acetylated (OAc) derivatives: squamocin (3 OAc) (11), molvizarin (3 OAc) (12), motrilin (3 OAc) (13) and methoxy methylated (MOM): squamocin (MOM) (14) and motrilin (MOM) (15), were prepared (Figure 2).

\section{Materials and Methods}

\subsection{Acetogenins}

Grinded seeds of $A$. squamosa were percolated with methanol. Solvent was evaporated to produce a crude $\mathrm{MeOH}$ extract which was then partitioned between $\mathrm{CHCl}_{3}$ and $\mathrm{H}_{2} \mathrm{O}$. The residue produced by further evaporation of the chloroformic phase was chromatographed on a silica gel column by using chloroform, ethyl and finally methanol as eluents. The isolation of ACG from the subextract was guided by thin layer chromatography (TLC) with the Kedde's reagent. Chromatographic fractions were processed on high-performance liquid chromatography (HPLC) by using RI detection, a Beckman C 18 column ( $5 \mu \mathrm{m}$ particle size, $25 \mathrm{~cm} \times 1 \mathrm{~cm}$ i.d.) and mixtures of methanol and water (90:10) as the mobile phase to yield pure ACG. Characterization of tested natural ACG was assessed by spectroscopic techniques (IR, ${ }^{1} \mathrm{H}-\mathrm{NMR},{ }^{13} \mathrm{C}-\mathrm{NMR}$, and MS) as well as $\alpha_{\mathrm{D}}$ determination, in comparison to previously reported data. 

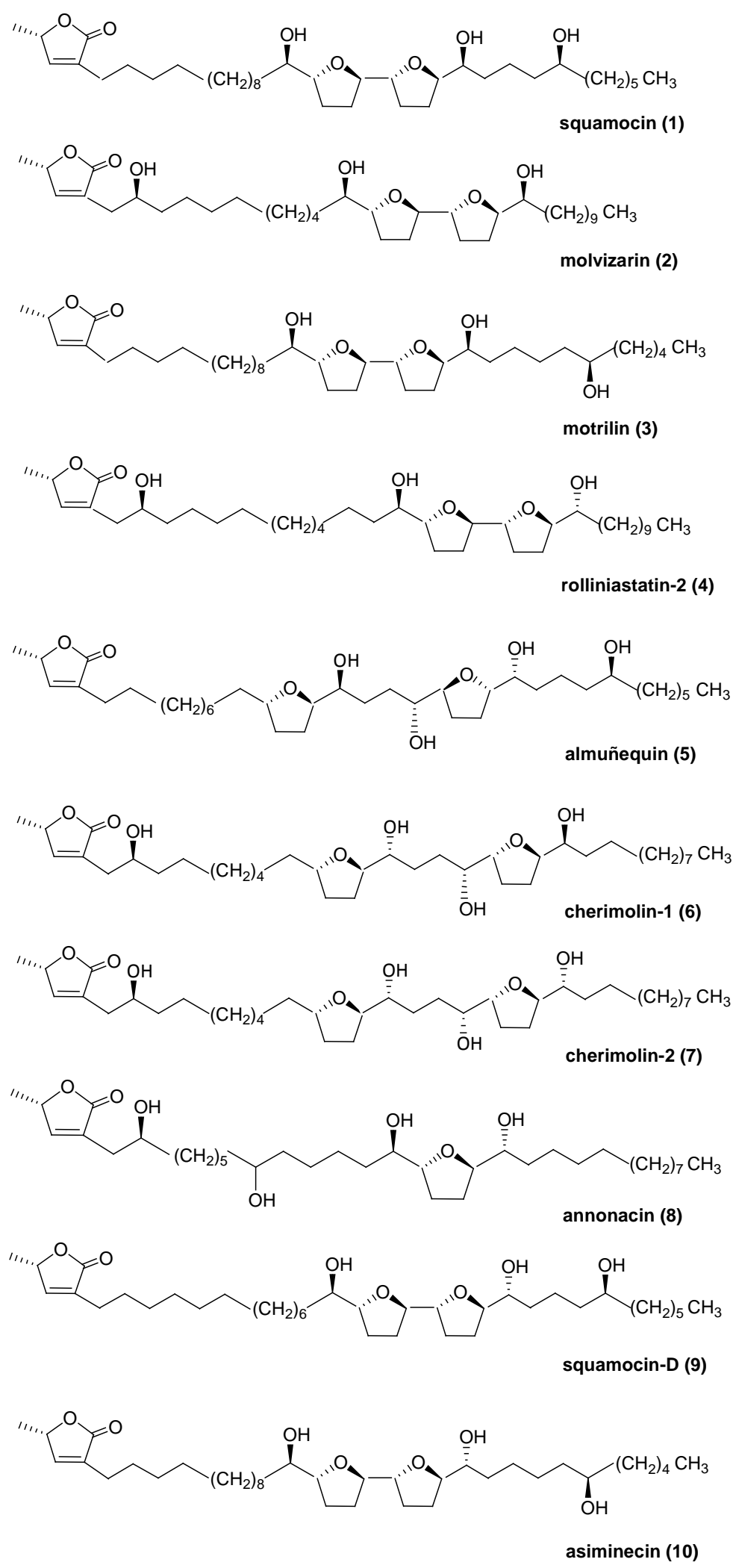

Figure 1. Natural ACG from A. squamosa methanolic seed extract evaluated for their nutritional alterations and toxic effects against $S$. frugiperda. 


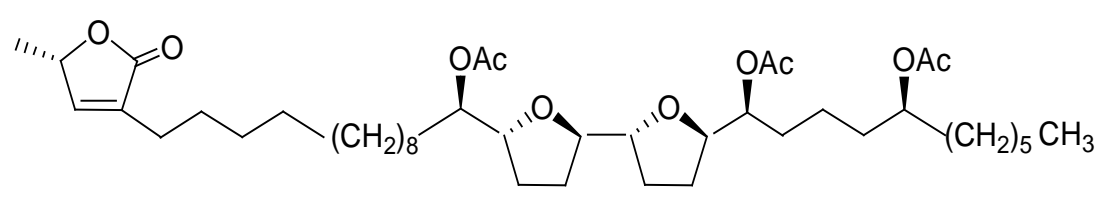

squamocin (30Ac) (11)

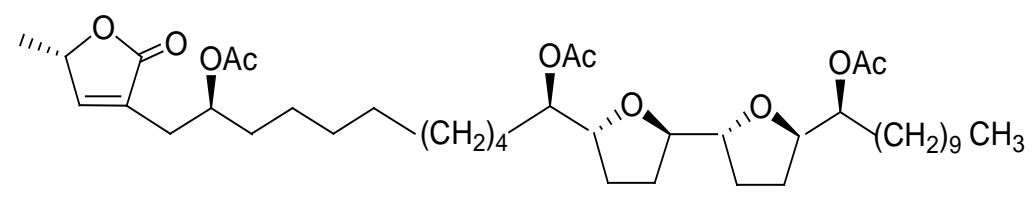

molvizarin (30Ac) (12)

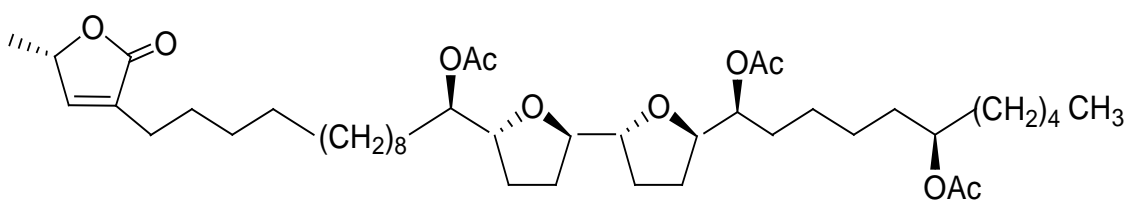

motrilin (3OAc) (13)

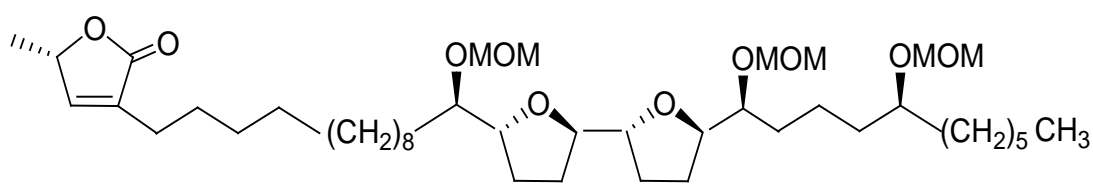

squamocin (MOM) (14)<smiles>CCCCCCC1=C[C@@H](C)OC1=O</smiles>

Figure 2. Structurally modified ACG: acetylated and methoxy methylated derivative evaluated for their nutritional alterations and toxic effects against $S$. frugiperda.

\subsection{Structural Modification of ACG}

Acetylated analogues, squamocin (3 OAc) (11), molvizarin (3 OAc) (12) and motrilin (3 OAc) (13) were obtained by chemical acetylation with acetic anhydride and addition of triethylamine $\left(25^{\circ} \mathrm{C}, \mathrm{N}_{2}\right.$ atmosphere) followed by solvent evaporation and purification on silica gel column. The compounds of interest were identified by high resolution spectroscopic methods $\left({ }^{1} \mathrm{H}\right.$ and $\left.{ }^{13} \mathrm{C}-\mathrm{NMR}\right)[20]$.

Methoxy methylated derivatives, squamocin (MOM) (14) and motrilin (MOM) (15) were obtained by adding $N, N$-diisopropylethylamine and methoxymethyl chloride to a dichloromethanic solution of natural ACG under a nitrogen atmosphere. The reaction was followed by TLC until the formation of products. MOM derivatives were purified by flash column chromatography. The identification of the bis-THF ACG methoxy methylated, were achieved by comparison of spectroscopic data ${ }^{1} \mathrm{H}-\mathrm{NMR}$ and ${ }^{13} \mathrm{C}-\mathrm{NMR}$ with the sample of the original ACG. 


\subsection{Test Insect and Diet}

Spodoptera frugiperda's natural life cycle is between 26 and 31 days. Females lay between 200 and 300 eggs for 5 to 6 days. Larvae emerge between 48 and $72 \mathrm{~h}$ and remain in this state between 12 and 15 days. Then, they pass to pupal stage where they remain for 7 days, after which the adults emerge. The larval diet of $S$. frugiperda consists in a mixture of yeast $(3 \mathrm{~g})$, boiled and milled bean $(250 \mathrm{~g})$, wheat germ $(12.5 \mathrm{~g})$, ascorbic acid (1.5 g), agar agar (12.5 g), methyl p-hydroxybenzoate $(1.5 \mathrm{~g})$, formaldehyde (4 mL of a $38 \%$ water solution), and water $(500 \mathrm{~mL})$.

\subsubsection{Treatment}

Natural ACG and their semisynthetic analogues solutions were prepared at $100 \mu \mathrm{g} / \mathrm{mL}$, all under the same conditions.

\subsubsection{No Choice Test}

Control larval diet is prepared by adding acetone to a portion of artificial diet $(10 \mathrm{~g})$. Another portion was impregnated with an acetonic solution of each ACG in order to leave $100 \mu \mathrm{g}$ of compound per $\mathrm{g}$ of diet (treated). After evaporation of the solvent, treated diets and control diet were placed in test tubes (20 replicates) in which second instar larvae were kept at $27^{\circ} \mathrm{C}$ and $60 \% \pm 15 \%$ relative humidity. When $50 \%$ of control diet had been eaten, control and treated diets were removed from the tubes and weighted accurately. Results of the no choice test were then reported by the feeding ratio FR50 = T/C [6], where $\mathrm{T}$ and $\mathrm{C}$ are the weights of diets consumed in the treated and control experiments, respectively.

\subsubsection{Toxicity Test}

Treated and control diets were placed in different test tubes (20 replicates for treated and 20 replicates for control experiments) in which second instar larvae were placed to be maintained at $27^{\circ} \mathrm{C}$ and $60 \% \pm 15 \%$ relative humidity until emergency of the first generation of adults. Larval developmental periods as well as mortality rates were recorded for treatments with all the ACGs (100 ppm) and control experiments [21].

\subsubsection{Nutritional Indices}

Similar second instar larvae were placed in several test tube at the beginning of the experiment and larval weight was measured. Test and control diets were also weighed and provided to larvae in each tube. Twenty replicates for control and twenty for each treatment were employed, tubes were kept at $27^{\circ} \mathrm{C}$. Weight variations produced by larval growth and diet addition were recorded. Average diet consumption (CI), growth rate (GR) and efficiency in the consumption index (ECI) were measured for a ten day period, starting with second instar larvae.

$$
\begin{gathered}
\mathrm{CI}=D / t \\
\mathrm{GR}=(A-B) / t \\
\mathrm{ECI}=(A-B) / D
\end{gathered}
$$


$D=$ Food eaten during the experiment period.

$A=$ Final larval weight.

$\mathrm{B}=$ Initial larval weight.

$t=$ Experiment period.

CI: Average daily diet consumption during the experiment.

GR: Average daily weight gain during the experiment.

CI, GR and ECI values were calculated for the experiment and control treatments. For comparison purposes, treatment-control ratio was calculated. Control ratio is considered 100\%. Values are expressed as (CIT/CIC) 100\%; (GRT/GRC) 100\% and (ECIT/ ECIC) $100 \%$ in the tables [21].

\subsection{Statistical Analysis}

The results are reported as mean values $\pm \mathrm{SD}$. The differences between the mean values were evaluated by analysis of variance (one way ANOVA). The Tukey test was used for all pair wise multiple comparisons of groups. $P>0.05$ were considered not significant difference between treatments [22].

\section{Results and Discussion}

\subsection{Annonaceous Acetogenins}

Chromatographic processes permitted the separation of 10 known ACG: squamocin (1) [23], molvizarin (2) [24], motrilin (3) [24], rolliniastatin-2 (4) [25], almuñequin (5) [26], cherimolin-1 (6) [4], cherimolin-2 (7) [4], annonacin (8) [27], squamocin D (9) [28] and asiminecin (10) [29] (Figure 1), that were exhaustively purified by reversed phase HPLC to be employed in the bioassays. The ACGs 4, 6, 7 and 10 had not been previously isolated from $A$. squamosa.Acetogenins represent around $0.07 \%$ of the seed weight.

ACG acetylated (OAc) derivatives: squamocin (3 OAc) (11), molvizarin (3 OAc) (12) and motrilin (3 OAc) (13), and their methoxy methylated (MOM) derivatives: squamocin (MOM) (14) and motrilin (MOM) (15) (Figure 2) were synthesized and purified, and then characterized by spectroscopic techniques (Table 1 and Table 2).

\subsection{No Choice Test}

As indicated in Table 1, the incorporation of $100 \mu \mathrm{g} / \mathrm{g}$ of diet of ACG squamocin into the artificial diet of $S$. frugiperda displayed the highest antifeedant effects $\left(\mathrm{FR}_{50}\right)$ followed by squamocin ( $3 \mathrm{OAc})(0.66 \pm 0.17$ and $0.77 \pm 0.14$; respectively), and caused a marked decrease in larval growth under the conditions of the experiment. The ACGs motrilin, motrilin (3 OAc), molvizarin and molvizarin (OAc) did not present a significant antifeedant action under the conditions of the experiment (Table 3).

\subsection{Toxicity of Annonaceous Acetogenins}

The results obtained in the tests of toxicity for each ACG show that all natural ACG, possesses a lethal effect on the $S$. frugiperda larvae in the early stages (Table 3 ) with 
Table 1. ${ }^{1} \mathrm{H}-\mathrm{NMR}$ data of $11,12,13,14$ and 15.

\begin{tabular}{|c|c|c|c|c|c|}
\hline \multirow{2}{*}{ Proton } & \multicolumn{5}{|c|}{${ }^{1} \mathrm{H}$ (shift in ppm) } \\
\hline & 11 & 12 & 13 & 14 & 15 \\
\hline 4 & - & $5.11(m 1 \mathrm{H})$ & - & - & - \\
\hline 13 & - & $4.94(m 1 \mathrm{H})$ & - & - & - \\
\hline 15 & $4.80(d t 1 \mathrm{H})$ & - & $3.90(d t 1 \mathrm{H})$ & $3.90(d t 1 \mathrm{H})$ & $3.39(d t 1 \mathrm{H})$ \\
\hline 22 & - & $4.85(m 1 \mathrm{H})$ & - & - & - \\
\hline 24 & $4.90(m 1 \mathrm{H})$ & - & $4.01(m 1 \mathrm{H})$ & $3.90(m 1 \mathrm{H})$ & $3.88(m 1 \mathrm{H})$ \\
\hline 28 & $4.80(m 1 \mathrm{H})$ & - & - & $3.40(m 1 \mathrm{H})$ & - \\
\hline 29 & - & - & $3.99(m 1 \mathrm{H})$ & - & $3.60(m 1 \mathrm{H})$ \\
\hline $4-(\mathrm{OAc})$ & - & $2.09(s 3 \mathrm{H})$ & - & - & - \\
\hline $13-(\mathrm{OAc})$ & - & $2.19(s 3 \mathrm{H})$ & - & - & - \\
\hline $15-(\mathrm{OAc})$ & $2.10(s 3 \mathrm{H})$ & - & $2.04(s 3 \mathrm{H})$ & - & - \\
\hline $22-(\mathrm{OAc})$ & - & $2.19(s 3 \mathrm{H})$ & - & - & - \\
\hline $24-(\mathrm{OAc})$ & $2.10(s 3 \mathrm{H})$ & - & $2.09(s 3 \mathrm{H})$ & - & - \\
\hline $28-(\mathrm{OAc})$ & $2.10(s 3 \mathrm{H})$ & - & - & - & - \\
\hline $29-(\mathrm{OAc})$ & - & - & $2.06(s 3 \mathrm{H})$ & - & - \\
\hline 15-(MOM) & - & - & - & $\begin{array}{l}4.70(s 2 \mathrm{H}) \\
3.50(s 3 \mathrm{H})\end{array}$ & $\begin{array}{l}4.65(s 2 \mathrm{H}) \\
3.37(s 3 \mathrm{H})\end{array}$ \\
\hline 24-(MOM) & - & - & - & $\begin{array}{l}4.70(s 2 \mathrm{H}) \\
3.50(s 3 \mathrm{H})\end{array}$ & $\begin{array}{l}4.69(s 2 \mathrm{H}) \\
3.37(\mathrm{~s} 3 \mathrm{H})\end{array}$ \\
\hline 28-(MOM) & - & - & - & $\begin{array}{l}4.70(s 2 \mathrm{H}) \\
3.50(s 3 \mathrm{H})\end{array}$ & - \\
\hline 29-(MOM) & - & - & - & - & $\begin{array}{l}4.74(s 2 \mathrm{H}) \\
3.39(s 3 \mathrm{H})\end{array}$ \\
\hline
\end{tabular}

Table $2 .{ }^{13} \mathrm{C}-\mathrm{NMR}$ data of $11,12,13,14$ and 15.

\begin{tabular}{|c|c|c|c|c|c|}
\hline \multirow{2}{*}{ Carbon } & \multicolumn{5}{|c|}{${ }^{13} \mathrm{C}$ (shift in ppm) } \\
\hline & 11 & 12 & 13 & 14 & 15 \\
\hline 4 & - & 72.00 & - & - & - \\
\hline 13 & - & 75.45 & - & - & - \\
\hline 15 & 73.50 & - & 75.19 & 74.08 & 74.08 \\
\hline 22 & - & 75.28 & - & - & - \\
\hline 24 & 75.00 & - & 75.40 & 71.23 & 71.23 \\
\hline 28 & 73.50 & - & - & 71.43 & - \\
\hline 29 & - & - & 71.92 & - & 71.43 \\
\hline $4-(\mathrm{OAc})$ & - & $21.23 a-170.69 c$ & - & - & - \\
\hline $13-(\mathrm{OAc})$ & - & $31.00 a-170.73 c$ & - & - & - \\
\hline $15-(\mathrm{OAc})$ & $21.50 a-170.76 c$ & - & $21.20 \mathrm{a}-170.68 \mathrm{c}$ & - & - \\
\hline $22-(\mathrm{OAc})$ & - & $31.00 a-170.96 c$ & - & - & - \\
\hline $24-(\mathrm{OAc})$ & $21.50 a-170.76 c$ & - & $21.22 \mathrm{a}-170.73 \mathrm{c}$ & - & - \\
\hline $28-(\mathrm{OAc})$ & $21.50 a-170.80 c$ & - & - & - & - \\
\hline $29-(\mathrm{OAc})$ & - & - & $21.11 \mathrm{a}-170.81 \mathrm{c}$ & - & - \\
\hline 15-(MOM) & - & - & - & $55.71 \mathrm{a}-96.82 \mathrm{~b}$ & $55.33 a-96.79 b$ \\
\hline 24-(MOM) & - & - & - & $56.67 a-96.73 b$ & $55.33 a-96.70 b$ \\
\hline 28-(MOM) & - & - & - & $55.73 a-96.13 b$ & - \\
\hline 29-(MOM) & - & - & - & - & $55.73 a-96.17 b$ \\
\hline
\end{tabular}

${ }^{\mathrm{a}}$ Methyl: $\mathrm{CH}_{3}$; ${ }^{\mathrm{b}}$ Methylene: $\mathrm{CH}_{2}$; ${ }^{\mathrm{c}}$ Carbonyl: $\mathrm{C}=\mathrm{O}$. 
Table 3. Antifeedant and toxic effects of natural and modified ACG on S. frugiperda.

\begin{tabular}{ccccc}
\hline Compounds & FR50a & $\begin{array}{c}(\%) \\
\text { Larval mortality }\end{array}$ & $\begin{array}{c}(\%) \\
\text { Pupal mortality }\end{array}$ & $\begin{array}{c}(\%) \\
\text { Emergency adults }\end{array}$ \\
\hline Control & - & 10 & 0 & 90 \\
Squamocin & $0.66 \pm 0.17$ & 100 & 0 & 0 \\
Molvizarin & $1.00 \pm 0.15$ & 100 & 0 & 5 \\
Motrilin & $1.09 \pm 0.15$ & 80 & 15 & 25 \\
Squamocin (3 OAc) & $0.77 \pm 0.14$ & 45 & 30 & 10 \\
Molvizarin (3 OAc) & $1.21 \pm 0.21$ & 60 & 30 & 20 \\
Motrilin (3 OAc) & $0.96 \pm 0.15$ & 80 & 0 & 85 \\
Squamocin (MOM) & $0.95 \pm 0.15$ & 15 & 0 & 90 \\
\hline Motrilin (MOM) & $0.98 \pm 0.19$ & 5 & 5 & \\
\hline
\end{tabular}

${ }^{\mathrm{a}}$ Mean $\pm \mathrm{SD}$.

high mortality effect at $100 \mu \mathrm{g} / \mathrm{g}$ of diet over than $80 \%$. The ACGs structurally transformed by acetylation showed less toxicity than natural ACGs (Table 3). The pupal mortality of squamocin (OAc), molvizarin (OAc) and motrilin were 30\%, 30\% and $15 \%$, respectively. It is apparently related to the observed malformations as shown in Figure 3(A) and Figure 3(B). The surviving adults showed malformations and decrease in size relative to the control (Figure 4(A) and Figure 4(B)), that led them to death before laying eggs. Significant increments in the duration of the larval stage where observed for all ACGs tested.

\subsection{Nutritional Indices}

According to results obtained on food consumption and its utilization, it has been observed that motrilin, squamocin (OAc) and molvizarin (OAc) at $100 \mu \mathrm{g} / \mathrm{g}$ of diet, influenced GR and ECI of instar larvae. A drop in ECI indicated that more food has been metabolized for energy and less has been converted to insect biomass (i.e., growth). These, resulted in an important larval growth decrease and subsequent significant larval mortality at very early stages in their life cycle and would reveal the presence of toxic compounds when compared with control $(P<0.05$, Tukey multiple range test). Motrilin ( $3 \mathrm{OAc}$ ) had the lowest consumption percentage and the lowest conversion of absorbed nutrient (Table 4). Although, the addition of $100 \mu \mathrm{g} / \mathrm{g}$ of MOM derivatives produced no significant toxic effects (Table 3 ) and changes in nutritional index values (Table 4) all emerged adults died within $24 \mathrm{~h}$.

The most important toxic action was observed with natural ACG against $S$. frugiperda larvae at the dose tested, following acetylated and MOM derivatives. These results are in agreement with a previous report from our team for other ACGs isolated from different species of Annonaceae [14]. 


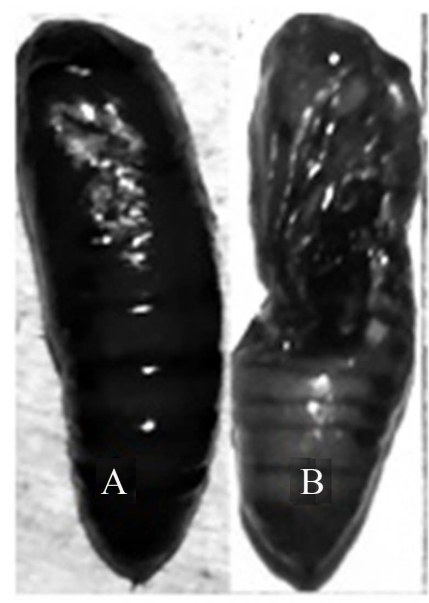

Figure 3. Pupae of $S$. frugiperda. (A) View of normal pupae; (B) Deformed pupae showing deficient melanization and malformation in wings, legs and antenna cover (molvizarin-3 OAc).

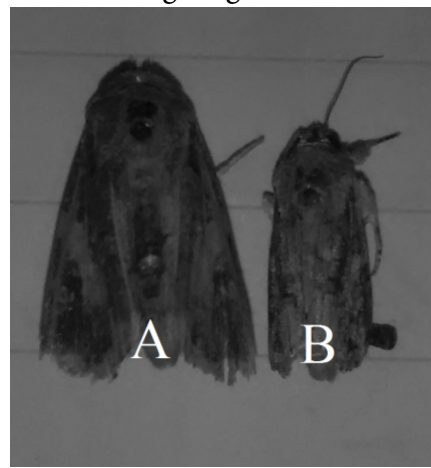

Figure 4. Adults of $S$. frugiperda. (A) View of untreated adult; (B) Treated adult (squamocin-3 OAc) showing malformation of wings and legs.

Table 4. Nutritional effects of natural and modified ACG on $S$. frugiperda.

\begin{tabular}{cccc}
\hline Compounds & ${\mathrm{CIT} / \mathrm{CIC}^{\mathrm{a}, \mathrm{b}}(\%)}$ & GRT/GRC $^{\mathrm{a}, \mathrm{b}}(\%)$ & ECIT/ECIC $^{\mathrm{a}, \mathrm{b}}(\%)$ \\
\hline Squamocin & $\mathrm{N} / \mathrm{D}$ & $\mathrm{N} / \mathrm{D}$ & $\mathrm{N} / \mathrm{D}$ \\
Molvizarin & $\mathrm{N} / \mathrm{D}$ & $\mathrm{N} / \mathrm{D}$ & $\mathrm{N} / \mathrm{D}$ \\
Motrilin & $77 \pm 2^{\mathrm{a}}$ & $12 \pm 2^{\mathrm{a}}$ & $16 \pm 2^{\mathrm{a}}$ \\
Squamocin (3 OAc) & $97 \pm 7^{\mathrm{d}}$ & $33 \pm 3^{\mathrm{a}}$ & $34 \pm 16^{\mathrm{a}}$ \\
Molvizarin (3 OAc) & $83 \pm 9^{\mathrm{b}, \mathrm{c}}$ & $47 \pm 10^{\mathrm{b}}$ & $56 \pm 12^{\mathrm{b}}$ \\
Motrilin (3 OAc) & $92 \pm 4^{\mathrm{c}, \mathrm{d}}$ & $85 \pm 16^{\mathrm{c}}$ & $92 \pm 17^{\mathrm{c}}$ \\
Squamocin (MOM) & $75 \pm 6^{\mathrm{a}}$ & $51 \pm 8^{\mathrm{b}}$ & $68 \pm 9^{\mathrm{b}}$ \\
Motrilin (MOM) & $78 \pm 5^{\mathrm{a}, \mathrm{b}}$ & $53 \pm 7^{\mathrm{b}}$ & $69 \pm 7^{\mathrm{b}}$
\end{tabular}

${ }^{\mathrm{a}}$ Numbers in columns represent mean $\pm \mathrm{SD}$. ${ }^{\mathrm{b}}$ Means within a column followed by the same letter are not significantly different $(P>0.05$, Tukey multiple range test). N/D: Not determined (Mortality at early instars).

Since hydroxyls groups flanking the THF have been blocked in MOM and acetylated derivatives a decrease in insecticidal activity is observed. This highlights the importance of the hydroxyl group to the insecticidal activity of natural ACG. 


\section{Acknowledgements}

Consejo Nacional de Investigaciones Científicas y Técnicas and Consejo de Investigaciones de la Universidad Nacional de Tucumán, Argentina. DST-India and MINCYTArgentina (P-06, 2015) for sanctioning grants for Indo-Argentina joint research project.

\section{References}

[1] Bermejo, A., Figadère, B., Zafra-Polo, M.C., Barrachina, I., Estornell, E. and Cortes, D. (2005) Acetogenins from Annonaceae: Recent Progress in Isolation, Synthesis and Mechanisms of Action. Natural Product Reports, 22, 269-303. http://dx.doi.org/10.1039/B500186M

[2] Alali, F., Liu, X. and McLaughlin, J. (1999) Annonaceous Acetogenins: Recent Progress. Journal of Natural Products, 62, 504-540. http://dx.doi.org/10.1021/np980406d

[3] Murray, B. and Leatemia, J. (2004) Toxicity and Antifeedant Activity of Crude Seed Extracts of Annona squamosa (Annonaceae) against Lepidopteran Pests and Natural Enemies. International Journal of Insect Science, 24, 150-158.

[4] Cortes, D., Myint, S., Dupont, B. and Davoust, D. (1993) Bioactives Acetogenins from Seeds of Annona cherimolia. Phytochemistry, 32, 1475-1482. http://dx.doi.org/10.1016/0031-9422(93)85162-K

[5] Alkofahi, A., Rupprecht, J.K., Anderson, J.E., McLaughlin, J.L., Mikolajczak, K. and Scott, B. (1989) Search for New Pesticides from Higher Plants. In: Arnason, J.T., Philogene, B. and Morand, A., Eds., Insecticides of Plant Origin, American Chemical Society, Washington DC, 25-43. http://dx.doi.org/10.1021/bk-1989-0387.ch003

[6] Cole, M.D. (1994) Key Antifungal, Antibacterial and Anti-Insect Assays-A Critical Review. Biochemical Systematics and Ecology, 22, 837-856.

http://dx.doi.org/10.1016/0305-1978(94)90089-2

[7] Moeschler, H., Pfluger, W. and Wendish, D. (1986) Annonin Insecticide. German Patent DE 3438763 A1.

[8] Moeschler, H., Pfluger, W. and Wendish, D. (1987) Pure Annonin and Process for the Preparation. US Patent 4689232.

[9] Mikolajczak, K., McLaughlin, J. and Rupprecht, J. (1988) Control of Pests with Annonaceous Acetogenins. US Patent 4721727.

[10] Mikolajczak, K., McLaughlin, J. and Rupprecht, J. (1989) Control of Pests with Annonaceous Acetogenins. US Patent 4855319.

[11] Raynaud, S., Fourneau, Ch., Laurens, A., Hocquemiller, R., Loiseau, Ph. and Bories, Ch. (2000) Squamocin and Benzyl Benzoate, Acaricidal Components of Uvaria. Planta Medica, 66, 173-175. http://dx.doi.org/10.1055/s-0029-1243125

[12] Shimada, H., Kozlowski, J.F. and McLaughlin, J.L. (1998) The Localisations in Liposomal Membranas of Thetetrahydrofuran Ring Moieties of the Annonaceous Acetogenins, Annonacin and Sylvaticin, as Determined by ${ }^{1} \mathrm{HNMR}$ Spectroscopy. Pharmacological Research, 37, 357-363. http://dx.doi.org/10.1006/phrs.1998.0314

[13] Shimada, H., Grutzner, J.B., Kozlowski, J.F. and McLaughlin, J.L. (1998) Membrane Conformation and Their Relation to Cytotoxicity of Asimicin and Its Analogues. Biochemistry, 37, 854-866. http://dx.doi.org/10.1021/bi9723481

[14] Di Toto Blessing, L., Budeguer, F., Ramos, J., Diaz, S., Bardón, A., Brovetto, M., Seoane, G. and Neske, A. (2015) Structural Factors of Annonaceous Acetogenins and Their Semisynthetic Analogues Related with Their Toxicity on Spodoptera frugiperda. Journal of Agri- 
cultural Chemistry and Environment, 4, 56-61. http://dx.doi.org/10.4236/jacen.2015.42006

[15] Guadaño, A., Gutiérrez, C., De La Peña, E., Cortes, D. and González-Coloma, A. (2000) Insecticidal and Mutagenic Evaluation of Two Annonaceous Acetogenins. Journal of Natural Products, 63, 773-776. http://dx.doi.org/10.1021/np990328+

[16] Álvarez Colom, O., Neske, A., Popich, S. and Bardón, A. (2007) Toxic Effects of Annonaceous Acetogenins from Annona cherimolia (Magnoliales: Annonaceae) on Spodoptera frugiperda. Journal Pest Science, 80, 63-67. http://dx.doi.org/10.1007/s10340-006-0149-2

[17] Di Toto Blessing, L., Álvarez Colom, O., Popich, S., Neske, A. and Bardón, A. (2010) Antifeedant and Toxic Effects of Acetogenins from Annona montana on Spodoptera frugiperda. Journal Pest Science, 83, 307-310. http://dx.doi.org/10.1007/s10340-010-0299-0

[18] Álvarez Colom, O., Neske, A., Barrachina, I., Ayala Mingol, I., Moya Sanz, P. and Bardón, A. (2008) Toxic Effects of Annonaceous Acetogenins on Oncopeltus fasciatus. Journal Pest Science, 81, 85-89. http://dx.doi.org/10.1007/s10340-007-0189-2

[19] Álvarez Colom, O., Salvatore, A., Willink, E., Ordóñez, R., Isla, M.I., Neske, A. and Bardón, A. (2010) Insecticidal, Mutagenic and Genotoxic Evaluation of Annonaceous Acetogenins. Natural Product Communications, 5, 391-394.

[20] Ramos, J.C., Bracco, P., Mazzini, M., Gamenara, D., Brovetto, M. and Seoane, G. (2010) XIV Antonio González Scientific Week. Universidad de la Laguna, Tenerife.

[21] Villafañe, E., Tolosa, D., Bardón, A. and Neske, A. (2011) Toxic Effects of Citrus aurantium and $C$. lemon Essential Oils on Spodoptera frugiperda (Lepidoptera: Noctuidae). Natural Product Communications, 6, 1389-1392.

[22] Statistix 7.1 (2000) Analytical Software.

[23] Kawasu, K., Alcántara, J. and Kobayashi, A. (1989) Isolation and Structure of Neoannonin, a Novel Insecticidal Compound from the Seeds of Annona squamosa. Agricultural and Biological Chemistry, 53, 2719-2722. http://dx.doi.org/10.1271/bbb1961.53.2719

[24] Cortes, D., Myint, S. and Hocquemiller, R. (1991) Molvizarin and Motrilin: Two Novel Cytotoxic Bis-Tetrahydro-Furanic $\gamma$-Lactone Acetogenins from Annona cherimolia. Tetrahedron, 47, 8195-8202. http://dx.doi.org/10.1016/S0040-4020(01)91014-2

[25] Pettit, G.R., Riensen, R., Leet, J.E., Polonsky, J., Smith, C.R., Schmidt, J.M., Dufresne, C., Schaufelberger, D. and Moretti, C. (1989) Isolation and Structure of Rolliniastatin-2, a New Cell Growth Inhibitory Acetogenin from Rollinia mucosa. Heterocycles, 28, 213-217. http://dx.doi.org/10.3987/COM-88-S6

[26] Fujimoto, Y., Murasaki, C., Shimada, H., Nishioka, S., Kakinuma, K., Singh, S., Singh, M., Gupta, Y.K. and Sahai, M. (1994) Annonaceous Acetogenins from the Seeds of Annona squamosa. Non-Adjacent Bis-Tetrahydrofuranic Acetogenins. Chemical and Pharmaceutical Bulletin, 42, 1175-1184. http://dx.doi.org/10.1248/cpb.42.1175

[27] McCloud, T.G., Smith, D.L., Chang, C.J. and Cassady, J.M. (1987) Annonacin, a Novel, Biologically Active Polyketide from Annona densicoma. Experiencia, 43, 947-949. http://dx.doi.org/10.1007/BF01951681

[28] Sahai, M., Singh, S., Singh, M., Gupta, Y.K., Akashi, S., Yuji, R., Asaki, H., Araya, H., Hara, N., Eguchi, T., Kakinuma, K. and Fujimoto, Y. (1994) Annonaceous Acetogenins from the seeds of Annona squamosa. Adjacent bis-Tetrahydrofuranic Acetogenins. Chemical and Pharmaceutical Bulletin, 42, 1163-1174. http://dx.doi.org/10.1248/cpb.42.1163

[29] Zhao, G.X., Miesbauer, L.R., Smith, D.L. and McLaughlin, J. (1994) Asimin, Asiminacin and Asiminecin: Novel Highly Cytotoxic Asimicin Isomers from Asimina triloba. Journal of Medicinal Chemistry, 37, 1971-1076. http://dx.doi.org/10.1021/jm00039a009 
Submit or recommend next manuscript to SCIRP and we will provide best service for you:

Accepting pre-submission inquiries through Email, Facebook, LinkedIn, Twitter, etc. A wide selection of journals (inclusive of 9 subjects, more than 200 journals)

Providing 24-hour high-quality service

User-friendly online submission system

Fair and swift peer-review system

Efficient typesetting and proofreading procedure

Display of the result of downloads and visits, as well as the number of cited articles

Maximum dissemination of your research work

Submit your manuscript at: http://papersubmission.scirp.org/

Or contact jacen@scirp.org 